\section{Qstetik}

Jurnal Bahasa Indonesia
Institut Agama Islam Negeri (IAIN) Curup, Indonesia

ISSN 2622-1810 (p); 2622-1829 (e)

volume 4, number 1, 2021 | page: 65-86

DOI: http://doi.org/10.29240/estetik.v4i1.2391

\title{
Nilai-Nilai Pendidikan Multikultural dalam Buku Teks di Sekolah Dasar Kelas Atas
}

\author{
Afni Laila Nafi'ah', Hilmy Mahya Masyhuda' \\ ${ }^{1}$ Institut Agama Islam Negeri (IAIN) Surakarta, ${ }^{2}$ Universitas Sebelas Maret, \\ Indonesia \\ hilmymahya5@gmail.com
}

\begin{abstract}
The value of multicultural education is very important to be taught to students not least at the elementary level unit education. This research will discuss the values of multicultural education in the texts in thematic textbooks at the elementary school level. This type of research uses library techniques with the object under study in the form of a textbook for elementary school students, and the class chosen in the textbook is class III-VI. In analyzing texts, researchers used qualitative research techniques and to obtain data researchers used reading and note-taking techniques. Besides the sampling technique or sampling is also taken by researchers so that the application is more directed at the data source in accordance with the problem. Content analysis techniques are also used to facilitate researchers in systematically organizing data collection. In the first data collection technique the researcher gave a signal to the data that wanted to be analyzed. Then the researcher categorizes the data according to the study, then an analysis is carried out by interpreting the categorized data. The results obtained in this analysis are Class III Integrated Thematic Textbooks VI has included multicultural education values such as educational values: tolerance, national spirit, love of the motherland or culture have been reflected in the texts presented in teaching materials. The quality of the content of multicultural education integrated in textbooks is adequate, although not all multicultural dimensions are well covered.
\end{abstract}

Keywords: Multicultural Education, Thematic Teaching Materials, Elementary School

Abstrak. Nilai pendidikan multikultural sangat penting diajarkan pada peserta didik tak terkecuali pada pendidikan tingkat satuan sekolah dasar. Pada penelitian ini akan dibahas mengenai nilai-nilai pendidikan multikultural yang ada pada teks-teks dalam buku ajar tematik tingkat sekolah dasar. Jenis penelitian ini menggunakan teknik kepustakaan dengan objek yang diteliti berupa buku ajar siswa sekolah dasar, dan kelas yang dipilih dalam buku ajar yaitu kelas III-VI. Dalam menganalisis teks, peneliti menggunakan teknik penelitian kualitatif dan untuk memperoleh data peneliti menggunakan teknik baca dan tenik catat. Selain itu teknik cuplikan atau sampling juga diambil peneliti agar penerapan lebih terarah pada sumber data yang sesuai dengan 
permasalahan. Teknik analisis isi juga digunakan untuk memudahkan peneliti dalam mengatur sistematis terkumpulnya data. Pada teknik pengumpulan data pertama peneliti memberi tanda terhadap data yang ingin dianalisis. Kemudian peneliti mengkategorikan data sesuai dengan kajian, baru dilakukan analisis dengan cara menafsirkan data yang telah dikategorikan. Hasil yang didapat dalam analisis ini adalah Buku Ajar Tematik Terpadu Kelas III s.d. VI telah memuat nilai-nilai pendidikan multikultural seperti nilai pendidikan: toleransi, semangat kebangsaan, demokrasi, cinta tanah air atau budaya telah tercermin dalam teks-teks yang disajikan dalam bahan ajar. Kualitas Muatan Pendidikan Multikultural yang diintegrasikan dalam buku ajar telah memadai, meski tidak semua dimensi multikultural tercakup dengan baik

Kata Kunci: : Pendidikan Multikultural, Bahan Ajar Bahasa Indonesia, Sekolah Dasar

\section{Pendahuluan}

Suatu bangsa terbentuk apabila dalam kelompok manusia itu terdapat nilai-nilai yang sama dan berkeinginan kuat untuk hidup bersama. Indonesia merupakan negara dengan luas terbesar ke-4 di dunia. Sebagai negara multikultural tak mengherankan jika ditemui berbagai heterogenitas suku, agama, budaya, bahasa, dan tradisi yang berbeda (Trisna, 2017:108), (Fatmawati dkk, 2018: 80). Kemajemukan tersebut akhirnya berdampak pada timbulnya beragam permasalahan sosial. Seperti pelajar yang terlibat tawuran bahkan sampai berujung pada pembunuhan. Kenyataan ini memerlukan penanganan yang tepat. Konsep kesadaran akan pentingnya toleransi, saling menghargai, dan kedamaian dapat diwujudkan melalui dunia pendidikan.

Seperti yang dipahami bersama bahwa pendidikan merupakan proses yang bertujuan untuk mengembangkan sumber daya manusia agar sumberdaya tersebut menjadi berkualitas. Kualitas yang diharapkan berupa kemampuan bersosial dan menciptakan individu yang optimal serta memberikan relasi terhadap masyarakat dan budaya yang berlaku (Ibrahim, 2013: 131). Dengan pendidikan tersebut seseorang akan memiliki rasa menghormati, menghargai, toleransi terhadap pihak lain yang berlatar belakang budaya, sosial dan agama selainnya. Pendidikan yang bertujuan spserti yang dimaksud di atas adalah pendidikan multikultural (Tasrif, 2015). 
Dasar terwujudnya multikultural adalah kebudayaan. Multikulturalisme mengakui dan mengagungkan perbedaan derajat, baik secara individu maupun dalam bentuk kebudayaan masyarakat (Ibrahim, 2013: 131). Hall memaparkan bahwa multikultural adalah karakteristik sosial komunitas budaya yang berbeda dan tinggal bersama serta berusaha membangun kehidupan bersama meskipun mereka mempertahankan identitas asli mereka (Rampersad, 2014). Pendidikan multikultural adalah pendidikan yang bertujuan untuk menanamkan rasa menghargai terhadap seseorang. Ismawati dkk (2019: 21) menyatakan bahwa multikultural dapat dipahami dengan landasan pengetahuan berupa keadilan, demokrasi, nilai-nilai budaya, agama, hak asasi manusia dan konsep lain yang relevan.

Indonesia merupakan negara yang luas dengan berbagai suku, budaya dan agama yang menaunginya. Terdapat kurang lebih 13.000 pulau di Indonesia, beragam keyakinan antara Islam, Hindu, Budha, Katolik, Kristen, Konghucu dan Protestan, serta jumlah suku yang menaunginya sekitar 300 suku dengan 200 bahasa yang berbeda (Indrapangastuti, 2014). Selain menjadi kekayaan budaya, banyaknya keberagaman tersebut memungkinkan timbulnya persoalan bagi Indonesia sendiri, seperti nepotisme, korupsi, kolusi, perseteruan, kekerasan, perusakan alam dan minimnya rasa kemanuisaan. Untuk itu, nilai-nilai multikultural perlu diterapkan sejak dini, salah satunya dengan cara menerapkannya pada pembelajaran di pendidikan dasar. Mahfud (2011: 200) menyatakan bahwa di Indonesia masih diperlukan usaha yang panjang dalam merevisi buku-buku pelajaran agar dapat mengakomondasi kontribusi dan partisipasi yang lebih inklusif bagi warga dari latar belakang suku/etnis, agama, dan budaya yang berbeda. Melalui uraian tersebut, muatan nilai multikultural dirasa penting untuk ditngkatkan dalam buku teks di sekolah dasar.

Prastowo (2012:172) menyatakan bahwa buku ajar terdiri atas lima komponen didalamnya, yaitu judul, kompetensi dasar yang dijadikan materi pokok, informasi pendukung yang mungkin bisa dikembangkan oleh guru, latihan dan penilaian. Penguatan pendapat tersebut dikemukakan oleh Sitepu (2012: 3) yang menyatakan bahwa belum banyak penulis buku ajar yang mengetahui unsur-unsur yang perlu ada 
dan harus diperhatikan dalam penulisan buku ajar. Selain itu, proses penerbitan buku tersebut juga melalui beberapa tahap berupa, editor, pengecekan aspek isi, bahasa dan desain dengan sudut pandang buku pelajaran sebagai sumber belajar.

Pemberlakuan tematik dalam kuriulum 2013, khususnya di jenjang SD, memerlukan hadirnya buku-buku ajar yang mengandung teks-teks sesuai dengan tujuan kurikulum. Guru berperan mengembangkan teks tersebut supaya mudah dicerna oleh peserta didiknya, sekaligus menyertakan pendidikan karakter dan multikultural (Irawati dan Zain, 2014: 83). Buku ajar merupakan salah satu alat penunjang keberhasilan pembelajaran (Mursida, 2017: 102). buku ajar tersebut akan lebih baik dan efektif digunakan jika guru mampu mengembangkan instruksi-instruksi yang ada didalamnya (Muklim, 2015: 39). Dalam hal ini peran guru sangat dibutuhkan, karena tidak setiap buku teks mencantumkan pendidikan tersebut didalamnya (Mahsun, 2014: 39).

Banks (2010: 23) menyatakan bahwa pendidikan multikultural memiliki lima dimensi yang saling berkaitan, yakni (1) content integration yaitu mengintegrasikan nilai budaya, (2) the knowledge contruction process yaitu membawa siswa untuk memahami implikasi budaya ke dalam mata pelajaran, (3) an equity pedagogy yaitu menyesuaikan metode pembelajaran, (4) prejudice reduction yaitu mengidentifikasi karaktersistik siswa, (5) empowering school culture and social culture yaitu mengonstruksi kultur sekolah dan struktur sosial.

Buku pelajaran yang baik harus mampu memberikan pemahaman yang mendasar dan menyeluruh mengenai keanekaragaman masyarakat dan kebudayaan. Oleh karena itu, aspek multikultural harus ada dan diintegrasikan dalam buku pelajaran. Dengan demikian perlu dilaukan analisis terhadap buku ajar siswa sekolah dasar. Apakah nilai-nilai multikultural telah terintegrasi dalam buku ajar. Dalam penelitian ini, buku ajar yang dianalisis adalah buku ajar siswa sekolah dasar (SD) kelas III-VI yang diterbitkan oleh Kementrian Pendidikan dan Kebudayaan. Hal ini didasarkan pada kebijakan pemerintah untuk menggunakan buku penunjang yang telah diterbitkan, terlebih dalam pengimplemntasian kurikulum 2013. 
Penelitian nilai pendidikan multikultural dalam buku teks sekolah dasar dengan konsep tematik belum pernah diteliti sebelumnya. Namun ada beberapa penelitian yang relevan yang menganalisis pendidikan multikultural pada teks. Seperti penelitian yang dilakukan Ismawati dkk (2019) dengan judul "Multikulturalisme Dalam Sastra Indonesia Sebagai Bahan Ajar" Penelitian tersebut mengacu pada teori yang dikemukakan oleh Harahap berupa multikulturalisme yang mencakup gagasan, cara pandang, kebijakan, penyikapan dan tindakan. Adapun dalam penelitian menggunakan teori analisis Banks. Kedua penelitian ini sama-sama menganalisis nilai multikulturalisme, perbedaannya terletak pada objek penelitian.

Penelitian Musim (2016) dengan judul "Nilai-Nilai Pendidikan Multikultural Dalam Buku Teks Bahasa Indonesia Untuk Siswa SMP" dan dipublikasikan di Jurnal Riksa Bahasa. Persamaan penelitian ini dengan penelitian yang peneliti lakukan adalah pada aspek kajiannya, yaitu pendidikan multikulturalisme, sedangkan perbedaannya adalah teori yang diganakan sebagai dasar untuk menganalisis teks. Pada penelitian yang dilakukan oleh muslim, pendidikan multikulturalisme diamati pada kegiatan siswa dalam merepresentasikan teori dalam buku teks, sedangkan penelitian yang peneliti lakukan hanya mengkaji konten buku teks di sekolah dasar.

Kemudian penelitian yang dilakukan Laila Fatmawati dkk (2018) dengan judul "Pengembangan Modul Pendidikan Multikultural Berbasis Karakter Cinta Tanah Air dan Nasionalis pada Pembelajaran Tematik". Penelitian ini hanya mengkaji tentang karakter cinta tanah air dan nasionalisme, sedangkan penelitian yang peneliti lakukan mencakup lima aspek yang menjadi dasar pendidikan multikultural menurut pendapat James A. Banks. Berdasarkan pemaparan tersebut, penelitian ini bertujuan untuk mendeskripsikan nilai multikultural yang terdapat dalam bahan ajar siswa sekolah dasar beserta penerapannya dalam kurikulum 2013, kemudian untuk mengetahui kualitas dari materi yang diajarkan.

Metode penelitian yang digunakan dalam mengkaji pendidikan multikultural dalam buku teks di sekolah dasar tingkat atas ini adalah metode kualitatif dengan pendekatan analisis isi. Dalam penelitian ini, 
pengumpulan data dilakukan dengan menghimpun berbagai literatur. Objek yang diteliti dalam penelitian kepustakaan berupa buku ajar siswa sekolah dasar yang diterbitkan oleh Kementrian Pendidikan dan Kebudayaan. Adapun kelas yang dipilih adalah kelas III-VI.

Nugrahani (2014: 107) menyatakan bahwa data dalam penelitian kualitatif berupa kata, ungkapan, kalimat dan tindakan. Data dalam penelitian ini adalah data yang berwujud kata, dialog dan teks-teks yang mengandung pendidikan multikultural dalam buku ajara bahasa Indonesia tingkat sekolah dasar. Sumber data utama dalam penelitian ini adalah teks yang ada dalam buku ajar tematik tingkat sekolah dasar. Peneliti dapat memulai pengumpulan data ketika arah dan tujuan penelitian sudah ditentukan. Dalam penelitian ini, teknik yang ditempuh oleh peneliti untuk memperoleh data adalah teknik baca dan tenik catat.

Teknik cuplikan atau sampling yang diambil oleh peneliti adalah sistem purposive sampling. Teknik pengambilan cuplikan secara purposive dipandang lebih mampu menangkap kelengkapan dan kedalaman data dalam menghadapi realitas yang tidak tunggal (Sutopo, 2002: 36). Penerapan teknik ini mengarahkan pada sumber data primer sesuai dengan permasalahan yang sedang diteliti. Pertama peneliti menentukan terlebih dahulu apa saja data yang akan dicari berdasarkan permasalahan, kemudian mencari sumber-sumber yang berkompeten guna mendapatkan data sesuai dengan yang diinginkan.

Teknik analisis data merupakan cara peneliti dalam mengatur secara sistematis terhadap data yang telah terkumpul melalui teknik pengumpulan data yang digunakan (Raco, 2010: 122). Dalam analisisnya, penelitian ini menggunakan teknik analisis interaktif. Seperti yang dikemukakan oleh Miles dan Huberman (dalam Sugiyono, 2012: 247) bahwa aktivitas dalam analisis data kualitatif dilakukan dengan cara interaktif dan berlangsung secara terus menerus samapai tuntas. Adapun langkah-langkah dalam menganalisis data dilakukan denganempat tahap, yaitu (1) pengumpulan data, (2) reduksi data, (3) penyajian data, dan (4) verifikasi dan penarikan kesimpulan.

\section{Hasil Penelitian}


Dalam penelitian ini, nilai pendidikan multikultural dikaji menggunakan lima dimensi multikultural yang disampaikan James A. Banks. Dalam pandangannya Banks menyampaikan lima dimensi multikultural, yakni pengintegrasian materi, pengurangan prasangka, penguatan budaya sekolah dan struktur sekolah, agama. Dimensi tersebut dapat terwakili melalui tiga aspek yang menjadi kerangka dasar nilai pendidikan, yaitu kebangsaan, kebudayaan, toleransi, dan demokrasi. Nilai-nilai tersebut dapat diuraikan sebagai berikut.

\section{Nilai Semangat Kebangsaan (Nasionalisme)}

Kebangsaan merupakan aspek yang mengkaji tentang semangat dalam membela negara. Hal tersebut berdasar pada rasa cinta tanah air dan menyadari pentingnya negara bagi kehidupannya. Aspek kajian nilai kebangsaan dapat ditemukan dalam buku ajar sekolah dasar dengan hasil penelitian sebagai berikut.

a. Buku Ajar Tematik Kelas V Tahun 2018

Nilai kebangsaan mengandung aspek cinta tanah air, semangat dalam menjalankan aturan dalam falsafah negara dan bangga bertanah air Indonesia. Pencerminan tersebut dapat berupa prilaku, ucapan maupun keyakinan. Aspek tersebut teraplikasikan dalam buku teks kelas V dengan tema ekosistem pada halaman 27, 49, 21. Tema peristiwa dan kehidupan halaman 76. Pencerminan aspek kebangsaan dapat dibuktikan dalam judul "sikap terhadap keberagaman budaya Indonesia" sebagai berikut.

"Keberagaman adalah kekayaan suatu negara yang tak ada batasnya dan juga patut dibanggakan. Banyak yang mengatakan bahwa Indonesia adalah negara yang unik yang memiliki keberagaman tradisi dan suku budaya ..... Oleh karena itu, sikap menghargai keberagaman tersebut dapat diwujudkan dengan bangga dengan negara sendiri" (Sabiyarti, 2019: 21).

Kutipan di atas menggambarkan kekayaan tradisi dan budaya di Indonesia. Kemudian sikap yang baik untuk menghargai kekayaan tersebut adalah dengan bangga menjadi warga negara Indonesia. Ungkapan tersebut mencerminkan rasa cinta tanah air pada diri 
seseorang. Dengan adanya pengetahuan tersebut, siswa di sekolah dasar dapat mengerti bahwa Indonesia memiliki kekayaan tradisi dan budaya yang kemudian memunculkan multikulturalisme dalam ideologi siswa. Rasa cinta tanah air diharapkan teraplikasikan dalam kehidupannya, sehingga mereka bangga bertanah air Indonesia serta melestarikan keberagaman budaya tersebut. Rasa bangga terhadap tanah air tersebut akan membuat seseorang untuk patuh pada aturan negara yang berlandaskan pada pancasila. Imbasnya adalah ketentraman untuk hidup sebagai warga negara Indonesia.

b. Buku Bahan Ajar Tematik Terpadu Praja Muda Karana untuk kelas III Sekolah Dasar

Nilai kebangsaan yang menjadikan negara Indonesia menjadi negara yang besar dan kuat adalah Lambang Negara. Lambang negara adalah lambang resmi yang dimiliki oleh sebuah negara. Nilai kebangsaan dapat ditunjukkan dalam teks berjudul 'Lambang Negara Indonesia' halaman 5 sebagai berikut.

" Lambang Negara suatu bentuk yang digunakan sebagai lambang resmi suatu negara. Garuda Pancasila adalah lambang negara kita. Indonesia memiliki lambang negara Garuda Pancasila. Lambang burung Garuda menggambarkan kebesaran dan kekuatan. Indonesia ingin menjadi negara yang besar dan kuat. .... Lambang negara Garuda Pancasila terdiri atas beberapa bagian. Kepala burung Garuda menoleh ke sebelah kanan. Pada leher burung Garuda terdapat perisasi yang menyerupai jantung. Leher, sayap, dan ekor memiliki bulu dengan jumlah tertentu. Perisai dilengkapi dengan lambang sila Pancasila. Kaki burung Garuda mencengkram pita yyang bertuliskan semboyan Bhoneka Tunggal Ika."

Kutipan di atas menggambarkan bahwa negara kesatuan, Indonesia memiliki lambang resmi yang digunakan oleh negara yaitu Garuda Pacasila. Sebagai warga negara Indonesia kita memiliki hak dan kewajiban terhadap masa depan bangsa Indonesia. Lambang negara kita 'Burung Garuda' memiliki nilai pendidikan multikultural yang terdapat pada cengkraman yang bertuliskan 'Bhinneka Tunggal Ika' yang artinya 
walaupun berbeda-beda tetapi tetap satu tujuan. Maksudnya kita hidup dalam negara yang sama harus tetap rukun dan menjaga persatuan bangsa. Kita semua sama, tidak ada yang membedakan, kita tetap satu yaitu Bangsa Indonesia.

c. Bahan Ajar Tematik Terpadu Praja Muda Karana untuk kelas III Sekolah Dasar

Nilai kebangsaan dalam Setiap negara salah satunya memiliki lagu kebangsaan yang menjadikan sebuah ciri, di negara Indonesia juga memiliki lagu kebangsaan, salah satunya adalah lagu Garuda Pancasila yang selalu dinyanyikan pada saat upacara bendera dilakukan. Hal tersebut dapat dibuktikan pada yang berjudul 'Mengenal Lagu Garuda Pancasila' Muatan Bahasa Indonesia halaman 7, sebagai berikut.

"Setiap hari Senin di sekolah Made dilakukan upacara bendera. Pada saat upacara selalu dinyanyikan lagu wajib atau lagu kebangsaan. Salah satu lagu kebangsaan yang sering dinyanyikan adalah Garuda Pancasila. ... Selain dalam upacara bendera hari Senin, biasanya pada kegiatan pramuka juga sering dinyanyikan lagu kebangsaan termasuk Garuda Pancasila".

Kutipan diatas menggambarkan bahwa masyarakat Indonesia yang patuh dan memghargai jasa para pahlawan Indonesia, misalnya setiap hari senin upacara bendera selalu dilakukan di sekolah ataupun instansi lainnya. Hal ini dilakukan untuk menghargai jasa para pahlawan dan mengenang jasa-jasa mereka. Dalam upacara bendera selalu menyanyikan Garuda Pancasila. Di dalam pramuka juga sama karena lagu garuda Pancasila memiliki arti bahwa warga negara indosesia akan selalu mendukung negara ini dan senantiasa untuk siap berjuang dan berkorban untuk rakyat Indonesia. Dalam pendidikan multikulturalisme tidak membedakan ras, suku dan agama begitupun makna dari garuda Pancasila yang pada dasarnya seluruh masyarakat Indonesia mendukung proklamasi dan berjiwa patriot.

d. Bahan Ajar Tematik Terpadu Praja Muda Karana untuk kelas III 
Nilai kebangsaan disetiap negara sangat penting, dengan keanekaragaman agama, suku, dan budaya menjadikan masyarakat tidak bisa saling mengerti. Berkat bahasa nasional kita dapat memahami satu sama lain. Semboyan bangsa Indonesia yaitu Bhineka Tunggal Ika yang artinya berbeda-beda tetapi tetap satu tujuan. Hal ini dapat ditunjukkan pada teks yang berjudul 'Makna Bhinneka Tunggal Ika' halaman 15.

"Negara Indonesia adalah negara kepulauan. Pulau-pulaunya didiami oleh berbagai suku bangsa. Keragamannya menyebabkan keragaan adat dan budaya. Keanekaragaman suku bangsa tidak menyebabkan perpecahan. Akan tetapi, makin memperkokoh dan memperkuat bangsa kita. Hal ini tercermin dalam semboyan kita. Kamu tentu sering mendengar 'Bhinneka Tunggal Ika'

Kutipan diatas menggambarkan bahwa, masyarakat Indonesia walau berbeda-beda agama, suku, dan budaya tetapi tetap satu tujuan. Yang diajarkan dalam pendidikan multikurltural yaitu bagaimana kita tetap sama dalam berbagai keadaan. Dalam makna bhinneka tunggal ika walau berbeda agama, suku, budaya dan bahasa daerahnya tapi kita semuanya tetap sama, merangkul satu sama lain tanpa membedakan.

\section{Nilai Penghargaan terhadap Kebudayaan}

Kebudayaan adalah aspek yang mengkaji tentang kekayaan budaya Indonesia. Selain itu, banyaknya budaya yang ada bukan menjadi landasan perpecahan, melainkan landasan persatuan sesuai dengan makna pancasila dan bhineka tunggal ika. Keberagaman tersebut perlu diketahui oleh peserta didik guna menyadari bahwa hal tersebut adalah unsur yang menjadi kebanggan bangsa ini. Aspek kajian nilai kebudayaan dapat ditemukan dalam buku ajar sekolah dasar dengan hasil penelitian sebagai berikut.

a. Buku Tematik Terpadu Kelas III, 2018

Aspek kebudayaan teraplikasikan dalam buku teks kelas V dengan tema makanan sehat pada halaman 49. tema organ gerak hewan dan manusia pada halaman 21. tema benda-benda disekitar kita pada halaman 96 dan 82. Pencerminan aspek kebudayaan terdapat dalam teks 
dengan judul "sikap terhadap keberagaman budaya Indonesia" sebagai berikut.

"Indonesia dikenal dengan keberagaman suku dan agama. Untuk suku sendiri ada suku jawa, suku batak, suku sunda, suku kalimantan dan lainnya yang memiliki keunikan dan khas tersendiri pada masing-masing daerah. Begitu pula dengan agama yang beragam seperti, Islam, Kristen, Katolik, Hindu, Budha dan Kongucu yang walaupun berbeda, namun tetap berprinsip pada Bhineka Tunggal Ika, meski berbeda tetapi tetap satu jua" (Sabiyarti, 2019: 20).

Kutipan di atas menunjukkan keeberagaman suku dan agama yang dimiliki Indonesia. Budaya yang ada pada tiap suku dan agama tersebut tentunya tidaklah sama. Namun mereka berlandas pada falsafah negara berupa pancasila dan bhineka tunggal ika. Mereka memiliki satu tujuan yaitu Indonesia. Dengan ditanamkannya nilai tersebut, berbagai daerah di Indonesia dengan suku mereka yang beragam akan memahami pentingnya menjaga persatuan dan kesatuan negara Indonesia. Dari sudut pandang tersebut, maka tampak jelas seberapa pentingnya pendidikan multikultural untuk ditanamkan pada bangsa Indonesia yang berimbas pada semakin kokohnya persatuan dan kesatuan. Selain itu, nilai tersebut juga menghindarkan masyrakat dari perang antar saudara yang telah terjadi sebelumnya. Alasan perpecahan tersebut terjadi adalah kurangnya penerapan pendidikan multikultural pada masyarakat khususnya pemahaman terhadap nilai kebudayaan

b. Buku Tematik Terpadu Kelas VI, 2018

Nilai kebudayaan juga terdapat dalam buku teks kelas VI dengan tema "Tumbuhan Sahabatku". Pada bagian ini siswa diarahkan untuk mengenal dan memahami budaya setiap negara. Kebudayaan yang terdapat dalam teks disajikan dengan menampilkan beragam tanaman yang menjadi penciri khas setiap negara. Hal tersebut dapat dibuktikan dalam tema tumbuhan sahabatku halaman 8 , sebagai berikut.

Bunga yang indah bukan hanya tumbuh di Indonesia. Negaranegara lain seperti negara tetangga pun memiliki bunga yang cantik. Karena kondisi geografis yang hampir sama, bunga 
yang tumbuh tidak jauh berbeda jenisnya. Perhatikan jenisjenis bunga yang tumbuh di negara-negara tetangga. Bunga kembang sepatu tumbuh di Indonesia dan Malaysia. Bunga ini dapat digunakan sebagai pewarna. Di Malaysia, bunga kembang sepatu dinamakan Bunga Raya dan merupakan bunga nasional.

Berdasarkan penggalan teks tersebut, siswa diarahkan untuk mengenal beragam jenis bunga yang terdapat di setiap negara. Keragaman tersebut membawa siswa untuk menghargai setiap keragaman budaya yang ada. Mereka akan memiliki sikap hormat pada simbol-simbol budaya tersebut. Dengan demikian, harapannya adalah dapat menciptakan kedamaian dalam menjalani kehidupan yang kaya akan kebudayaan ini.

\section{Nilai toleransi}

Toleransi mengkaji tentang kehidupan bermasyarakat yang berdampingan dengan beragam keyakinan, etnis, kultur dan derajat. Respon tenggang rasa antara mereka adalah kajian utama dalam aspek toleransi. Aspek kajian nilai toleransi dalam buku ajar sekolah dasar dengan hasil penelitian sebagai berikut.

a. Buku Tematik Terpadu Kelas V, 2018

Toleransi mengkaji tentang kehidupan bermasyarakat yang berdampingan dengan beragam keyakinan, etnis, kultur, pekerjaan dan derajat. Respon tenggang rasa antara mereka adalah kajian utama dalam aspek toleransi. Aspek tersebut teraplikasikan dalam buku teks kelas V dengan tema udara bersih bagi kesehatan pada halaman 85. Dalam halaman tersebut terdapat teks dengan judul "menghargai kegiatan ekonomi orang lain". pencerminan aspek toleransi terdapat dalam kutipan berikut.

"tujuan utama orang bekerja dalah untuk memenuhi kebutuhan hidupnya. Ada yang menjadi petani, nelayan, karyawan pabrik, pegawai negeri, pengusaha, guru ataupun polisi. Perkerjaan atau usaha setiap orang dalam memenuhi kebutuhan hidupnya tersebut haruslah kita hargai..... Tidak 
boleh menghina pemulung, alasannya, semua pekerjaan halal adalah pekerjaan mulia......" (Sabiyarti, 2019: 85).

Kutipan diatas menggambarkan bagaimana nilai-nilai pendidikan multikultural berupa toleransi antar sesama sangat diperhatian dalam upaya untuk menjaga persaudaraan. Dalam kutipan tersebut disebutkan berbagai macam pekerjaan manusia dalam tingkatan yang berbeda-beda pula. Pekerjaan merupakan upaya manusia dalam memeroleh rezeki guna memenuhi kebutuhannya. Upah dari setiap pekerjaan tentunya berbeda. Namun, pada kutipan di atas, mengarahkan siswa untuk selalu menghargai setiap pekerjaan yang dimiliki seseorang selama pekerjaan itu halal. Rasa toleransi antar sesama akan menghasilkan kehidupan yang rukun dalam wujud persaudaraan. Dalam hal ini dapat disadari bahwa pendidikan multikultural perlu ditanamkan pada peserta didik dalam upaya menjaga kerukunan di lingkungan sekolah, keluarga maupun dalam berbagai aktifitasnya.

b. Buku Tematik Terpadu Kelas VI, 2018

Nilai toleransi juga ditunjukkan dari buku teks kelas VI pada halaman 24. Pada bagian ini siswa diarahkan untuk menganalisis nilainilai yang terdapat dalam ke lima sila pancasila. Salah satu sila yang mengandung nilai toleransi adalah sila 1, Ketuhanan Yang Maha Esa. Hal tersebut dapat dibuktikan dalam buku teks kelas 6 pada halaman 24, sebagai berikut.

"Di hari libur, Lani dan teman-temannya merencanakan untuk berkumpul di rumah Edo. Mereka berencana membuat minuman dari jahe. Namun alangkah kagetnya Lani, Udin, Siti, Dayu, dan Beni. Edo ternyata sedang sakit. Mereka akhirnya bersepakat membuatkan wedang jahe untuk Edo. Di belakang rumah Edo banyak tanaman jahe. Edo sangat senang. Persahabatan mereka sangat indah. Mereka memiliki latar belakang yang berbeda. Namun, semangat tolong menolong di antara mereka sangat tinggi".

Penggalan teks yang terdapat pada bahan ajar siswa sekolah dasar kelas VI tersebut merepresentasikan bahwa tedapat nilai multikultural yang ingin disampaikan, yakni toleransi. Dengan latar belakang yang 
berbeda, semangat tolong-menlong mereka terhadap sesama sangat tinggi. Hal ini diharapkan mampu memberikan pemahaman pada siswa bahwa perbuatan baik dapat dilakukan pada siapapun tanpa harus memandang latar belakang orang tersebut.

\section{Nilai Demokratis}

Demokratis merupakan salah satu nilai dari nilai pendidikan karakter yang diterapkan dalam kurikululum pendidikan. Nilai pendidikan demokratis mencakup mengenai toleransi yaitu mengharagai hak dan kewajiban orang lain tanpa memaksakan kehendak pribadi, lalu nilai bebas mengemukakan pendapat merupakan sikap memberikan saran dan tanggapan tanpa merugikan orang lain. Nilai demokratis ini ditunjukkan dalam Buku Tematik Terpadu kelas IV, 2018.

Pada teks, paragraf pertama tertulis "Musim hujan hampir tiba. Warga desa Kampung Babakan berdiskusi untuk melakukan kerja bakti. Mereka berencana membersihkan selokan. Mereka sepakat ketika selokan bersih warga tidak akan kebanjiran." Pesan yang ingin disampaikan dalam teks adalah bagaimana sebuah kelompok atau organisasi mampu bergerak bersama tanpa membedakan latar belakang agama, sosial, dan sebagainya. Setiap individu memiliki kebebasan untuk menyampaikan aspirasinya. Dari penggalan teks tersebut, penulis berusaha untuk menanamkan sikap demokratis terhadap sesama.

\section{Pembahasan}

\section{Muatan Pendidikan Multikultural dalam Buku Ajar Tematik Siswa Sekolah Dasar}

Maraknya kenakalan remaja yang terjadi di beberapa daerah menunjukan rendahnya nilai moral yang dimiliki. Seperti yang diketahui, bahwa mereka yang terlibat tawuran adalah pelajar tingkat SMA-SMP. Dari kondisi inilah diperlukan adanya penanaman pendidikan multikultural sejak sekolah dasar. Maria (2010:78) menegaskan bahwa pendidikan multikultural adalah jawaban atas beberapa problematika kemajemukan. Jadi, pendidikan multikultural adalah sebuah keniscayaan. Artinya, pelaksanaan pendidikan multikultural menjadi sebuah keharusan dan tidak bisa dielakkan. 
Integrasi pendidikan multikultural sekolah dasar dapat dilakukan melalui penggunaan bahan ajar. Berdasarkan hasil analisis secara keseluruhan terhadap buku ajar tematik siswa sekolah dasar mulai dari kelas III-VI, buku tersebut telah mengintegrasikan pendidikan multikultural. Dari lima dimensi multikultural Banks yang terbagi menjadi empat belas subdimensi, ternyata buku tersebut hanya memuat 4 dimensi yang terbagi dalam beberapa subdimensi. Keempat dimensi tersebut meliputi dimensi integrasi materi, pengurangan prasangka, konstruksi pengetahuan, penguatan budaya sekolah dan struktur sosial. Adapun subdimensinya meliputi dimensi agama, budaya, keadilan, demokrasi, budaya sekolah, sosial. pendidikan multikultur. Namun tidak semua dimensi multikultural terdapat dalam masing-masing buku tematik tersebut. Berikut uraian lengkap mengenai subdimensi dalam buku ajar tematik siswa sekolah dasar.

a. Subdimensi Budaya (Mewakili Dimensi Integrasi Materi)

Pengenalan dan pemahaman terhadap berbagai budaya yang terdapat di Indonesia sanagt diperlukan. Hal ini dilakukan agar siswa memiliki sikap dan perilaku yang dapat memahami, menghormati, dan menhargai berbagai budaya yang berbeda-beda. Berdasarkan hasil penelitian, subdimensi budaya ini tereprentasikan dalam "Buku Ajar Tematik Terpadu Kelas V dan VI " yang diterbitkan oleh Kementrian Pendidikan dan Kebudayaan.

b. Subdimensi Status Sosial Ekonomi (Mewakili Dimensi Pengurangan Prasangka)

Pengurangan prasangka terhadap sesame, baikdari segi agama, suku, ras, etnis, maupun status sosial ekonomi harus dilakukan. Ketimpangan antara mayoritas dan minoritas harus diminimalisir. Semua pihak harus menjaga agar tetap terjalin sebuah kehidupan yang harmonis antarsesama.

Subdimensi status sosial ekonomi dapat ditemukan dalam buku tematik terpadu kelas III. Dalam penggalan teks yang terdapat dalam buku tersebut memuat nilai persamaan hak dan kewajiban orang lain. Artinya pentingnya penghargaan dan penghormatan terhadap berbagai 
latar belakang sosial ekonomi. Sudah menjadi keharusan, nilai-nilai penghargaan dan penghormatan dimiliki dan diaplikasikan setiap individu. Oleh karena itu, siswa diharapkan memiliki sikap dan perilaku yang positif dalam menyikapi adanya berbagai status sosial ekonomi yang berada di sekeliling mereka.

c. Subdimensi Budaya Sekolah (Mewakili Dimensi Penguatan Budaya Sekolah dan Struktur Sosial

Budaya sekolah yang berkaitan dengan sikap dan perilaku yang saling menyayangi, menolong, toleransi senantiasa dipupuk siswa. Hal ini diperlukan agar interaksi mereka di sekolah maupun di laur sekolah dapat berlangsung dengan baik. Dengan harapan dapat mewujudkan suasana pergaulan yang rukun antarsesama.

Pengintegrasian nilai-nilai pendidikan multikultural, khususnya subdimensi budaya sekolah dapat ditemukandalam buku tematik teradu kelas V dan VI sekolah dasar. Dalam kedua buku tersebut disajikan beragam contoh mengenai pentingnya menjaga kerukunan dan toleransi dalam lingkup sekolah. Bacaan yang ditampilkan berupaya untuk memberikan pemahaman mengenai pentingnya menjaga komunikais, keterbukaan, saling menghargai dan menghormati.

\section{d. Subdimensi Kebangsaan/Kelompok (Mewakili Konstruksi Pengetahuan)}

Nilai pendidikan multikultural dapat diterapkan melalui mengkonstruksi pengetahuan siswa mengenai semangat nasionalisme. Dengan pemahaman adanya sejarah bangsa, maka akan tercipta rasa menghargai perjuangan para pahlwana yang telah gugur di medan perang. Dengan adanya pengetahuan yang baik, maka akan memunculkan semangat dalam menjalankan aturan dalam falsafah negara dan bangga bertanah air Indonesia. Pencerminan tersebut dapat berupa prilaku, ucapan maupun keyakinan.

Nilai kebangsaan atau semangat nasionalisme ini tercermin dalam buku tematik terpadu kelas III. Dalam buku tersebut disajikan beberapa bacaan mengenai semangat nasionalisme. Unsur pancasila dan bhineka tunggal ika banyak disinggung dalam teks tersebut. Melalui pendidikan 
multikultural inilah akan membentuk jiwa peserta didik yang berjiwa pancasila.

\section{Penguatan Pendidikan Multikultural Melalui Bahan Ajar bahasa Indonesia Kurikulum 2013}

Tidak dapat dipungkiri bahwa Indonesia adalah bangsa yang kaya akan keragaman budaya. Jika keragaman ini tidak dianggap sebagai anugrah Tuhan, maka perang antaretnis akan terus terjadi. Oleh karena itu, sudah menjadi kewajiban untuk menanamkan pendidikan multikultural pada siswa sejak sekolah dasar. Pendidikan multikultural berfungsi sebagai sarana alternatif pemecahan konflik. Indonesia dengan masyarakat plural sangat rentan terhadap konflik. Kondisi ini menunjukkan bahwa nilai toleransi sangat kurang. Pendidikan multukultural hadir dengan membawa harapan pada semua bahwa hidup saling menghormati dan menghargai perbedaan.

Secara spesifik, Banks menyatakan pendidikan multikultural meliputi lima dimensi, yakni Content Integration, The Knowledge Contruction Process, An Equity Paedagogi, Prejudice Reduction, Empowering School Culture and Social Culture. Kelima dimensi tersebut mengonstruksikan penerapan budaya, bahasa, dan sastra dalam kurikulum sekolah. Siswa diberi kesempatan untuk mengembangkan potensi yang dimiliki. Selain itu, kurikulum juga harus menanamkan kepada siswa untuk mengerti keberadaan kelompoknya dan cara beradaptasi dengan situasi etnik yang plural (Simamora, 2015:66).

Salah satu komponen tercapainya tujuan kurikulum adalah bahan ajar. Sebagai alat, bahan ajar digunakan untuk mewujudkan rumusanrumusan capaian pembelajaran (CPL) sesuai kerangka kurikulum. Dalam kurikulum 2013, pendidikan multikultural diintegrasikan dalam bentuk teks-teks bacaan yang terdapat dalam bahan ajar. Pada pendidikan dasar, khususnya sekolah dasar telah mengintegrasikan nilai-nilai multikultural dalam bahan ajar tematik. Sub dimensi toleransi, semangat kebangsaan, cinta tanah air atau budaya telah tercermin dalam teks-teks yang disajikan dalam bahan ajar. Pengintegrasian ini menjadi hal yang sangat penting dilakukan mengingat kemajemukan dan keberagaman budaya dari siswa. Dengan adanya pengintegrasikan pendidikan multikultural 
dalam kurikulum sekolah, diharapkan mampu membentuk sikap untuk saling menghargai budaya multikultural yang ada.

\section{Kualitas Muatan Pendidikan Multikultural dalam Buku Ajar Bahasa Indonesia Siswa Sekolah Dasar}

Muatan nilai-nilai multikultural dalam buku teks di sekolah dasar berupa nilai semangat kebangsaan pada buku teks kelas V dan kelas III, nilai penghargaan terhadap kebudayaan pada buku teks kelas III dan VI, nilai toleransi pada buku teks kelas V dan VI, dan nilai demokratis pada buku teks kelas VI. Berdasarkan hasil analisis mengenai nilai-nilai multikulturalisme dalam buku ajar tematik siswa sekolah dasar dari kelas III-VI diperoleh fakta bahwa buku tersebut telah mengintegrasikan nilai multikultural.

Nilai pendidikan multikulturan akan lebih ditekankan lagi seiring tingkat pemikiran siswa. Di tingkat SMP misalnya, Agustinova (2018) mengungkapkan bahwa nilai multikulturan yang termuat dalam buku teks tingkat SMP adalah nilai pengakuan adanya budaya masyarakat, mengakui hak asasi manusia, rasa tanggung jawab antar sesama dan tanggung jawab atas lingkungan sekitar. Sementara pada tataran SMA, Rohmat (2016) mengungkapkan bahwa muatan nilai multikultural yang terdapat dalam buku teks di SMA adalah nilai persamaan hak, toleransi sosial dan budaya, keadilan, persaudaraan dan etika pergaulan. Perbedaan nilai multikultural di tingkat sekolah dasar dan sekolah menengah tersebut dipengaruhi oleh daya pikir siswa dan seberapa banyak pengalaman yang didapat oleh peserta didik. Semakin tinggi tingkat pendidikannya, maka semakin berbobot pula nilai multikultural yang harus dipahaminya.

Kualitas muatan pendidikan multikultural yang diintegrasikan dalam buku ajar telah memadai, meski tidak semua dimensi multikultural tercakup dengan baik. Hal ini dapat ditunjukkan dari materi, latihan soal, dan evaluasi yang diberikan pada siswa. Seperti materi mengenal keragaman budaya. Teks yang dimunculkan tidak hanya budaya lokal saja, akan tetapi mampu mencakup ranah dunia atau internasional. Meski sudah termasuk dalam kategori memadai dan layak untuk diaplikasikan dalam proses pembelajaran, namun masih perlu adanya perbaikan baik 
mengenai konteks teks, latihan soal, tugas-tugas, maupun evaluasi yang diberikan kepada peserta didik.

Perlunya perbaikan atau revisi pada buku ajar bertujuan agar pendidikan multikultural yang dicanangkan dapat terwujud sesuai tujuan pendidikan nasional yang telah ditetapkan. Seperti pandangan yang disampaikan Effendy (2009:6) bahwa masyarakat multikultural baru yang dikehendaki bangsa ini adalah manusia yang "Cerdas" (cerdikpandai, energik-kreatif, responsif terhadap masyarakat demokratis, daya guna, akhlak mulia, dan sopan santun). Dengan adanya masyarakat yang cerdas, keselarasan dan keseimbangan dalam menghadapi pluralitas hidup berbangsa dan bernegara dapat berjalan secara seimbang.

\section{Kesimpulan}

Penelitian mengenai nilai-nilai pendidikan multikultural dalam buku ajar siswa sekolah dasar dapat disimpulkan sebagai berikut.

Pertama. Muatan pendidikan multikultural dalam buku ajar tematik siswa sekolah dasar berupa subdimensi budaya yang mereprentasikan dalam "Buku Ajar Tematik Terpadu Kelas V dan VI, subdimensi status sosial ekonomi dapat ditemukan dalam buku tematik terpadu kelas III, subdimensi budaya sekolah dapat ditemukan dalam buku tematik teradu kelas V dan VI sekolah dasar, subdimensi kebangsaan/kelompok dalam buku tematik terpadu kelas III.

Kedua. Penguatan pendidikan multikultural melalui bahan ajar tematik kurikulum 2013 pada pendidikan dasar, dapat dijumpai dengan wujud subdimensi toleransi, semangat kebangsaan, cinta tanah air atau budaya telah tercermin dalam teks-teks yang disajikan dalam bahan ajar. Pengintegrasian ini menjadi hal yang sangat penting dilakukan mengingat kemajemukan dan keberagaman budaya dari siswa.

Ketiga. Kualitas muatan pendidikan multikultural yang diintegrasikan dalam buku ajar telah memadai, meski tidak semua dimensi multikultural tercakup dengan baik. Hal ini dapat ditunjukkan dari materi, latihan soal, dan evaluasi yang diberikan pada siswa. Seperti materi mengenal keragaman budaya 
Hasil penelitian ini diharapkan dapat memberikan kontribusi positif bagi seluruh pihak yang berkepentingan (penulis, guru, akademisi, pengambil kebijakan) hendaknya juga dapat memerhatikan segala sesuatu yang berkaitan dengan nilai-nilai pendidikan multikultural dalam bahan ajar tematik siswa sekolah dasar.

\section{Bibliografi}

Agustinova, Danang Ade.2018.Nilai-Nilai Pendidikan Multikultural Dalam Buku Teks Non-Bse Mata Pelajaran IPS Untuk Siswa SMP Kelas VII, VIII Dan IX Terbitan Pusat Perbukuan. Skripsi.Yogyakarya: Universitas Negeri Yogyakarta.

Angi St. Anggari, dkk. 2017. Indahnya Kebersamaan merupakan Buku Tematik Terpadu Kuriukulum 2013 edisi revisi.. Jakarta: Pusat Kurikulum dan Perbukuan, Balitbang, Kemendikbud.

Angi St. Anggari, dkk. 2018. Selamatkan Makhluk Hidup. Jakarta: Pusat Kurikulum dan Perbukuan, Balitbang, Kemendikbud.

Banks, James A. 2009. The Routledge Internasional Companion to Multicultural Education. New York: Routledge.

Banks, James A. 2010. The Canon Debate, Knowladge Construction and Multicultural Education. American Educational Research Assosiation, 22 (5), 4-14.

Basuki, Wulandayani Ngujer dkk. 2015. Analisis Isi Buku Ajar Bahasa Indonesia Wahana Pengetahuan Untuk Smp/Mts Kelas VIII. Basastra: Jurnal Penelitian Bahasa, Sastra Indonesia dan Pengajarannya, 3(2).

Cresswell, Jhon. 2015. Riset Pendidikan: Perencanaan, Pelaksanaan dan Evaluasi Riset Kualitatif dan Kuantitatif. Yogyakarta: Pustaka Pelajar.

Fatmawati, Laila, Rani Dita Pratiwi, Vera Yuli Erviana. 2018. Pengembangan Modul Pendidikan Multikultural Berbasis Karakter Cinta Tanah Air Dan Nasionalis Pada Pembelajaran Tematik. Jurnal Pendidikan dan Kebudayaan, 8 (1).

Ibrahim, Rustam. 2013. Pendidikan Multikultural: Pengertian, Prinsip, dan Relevansinya dengan Tujuan Pendidikan Islam. Addin, 7 (1).

Idris, Zahara. 1987. Dasar-Dasar Kependidikan. Padang: Angkasa Raya. Indra, Pangastuti.2014.Praktek dan Problematik Pendidikan Multikultural 
di SMK. Jurnal Pembangunan Pendidikan Volume 2 Nomor 1 Tahun 2014.

Irawati, Retno Purnama dan Zaim Elmubarok. 2014. Pengembangan Buku Ajar Bahasa Indonesia Tematik Berkarakter Bagi Siswa SD Melalui Sastra Anak. Jurnal Pendidikan Karakter 4 (2).

Ismawati dkk. 2019. Multikulturalisme dalam Sastra Indonesia Sebagai Bahan Ajar Apresiasi Sastra. Jurnal Pendidikan Bahasa, 8 (1).

Karli, Hilda. 2020. Penerapan Pembelajaran Tematik SD di Indonesia. Humaniora, 2 (1).

Khair, Ummul. 2018. Pembelajaran Bahasa Indonesia dan Sastra di SD dan MI. Jurnal Pendidikan Dasar, 2 (1).

Kusaeri. 2012. Metodologi Penelitian. Surabaya: Government of Indonesia (GoI) and Islamic Development Bank (IDB).

Mahfud, Choirul. 2011. Pendidikan Mutikultural. Yogyakarta: Pustaka Pelajar.

Mahsun. 2013. Teks dalam Pembelajaran Bahasa Indonesia. Jakarta:Rajawali Pers

Mahsun. 2014. Teks Pembelajaran Bahasa Indonesia Kurikulum 2013. Jakarta: Raja Grafindo Persada.

Miftah, M. 2016. Multicultural Education In The Diversity Of National Cultures. Qudus. $\quad$ International Journal Of Islamic Studies, 4 (2).

Muklim, Marlia. 2015. Bahasa Indonesia dalam Buku Ajar. Jurnal Pendidikan, Pengajaran Bahasa dan Sastra, 1(1).

Mursida, Iva. 2017. Pengembangan Buku Ajar Bahasa Indonesia Bermuatan Nilai-Nilai Karakter Menggunakan Model Pembelajaran Berbasis Masalah. Edu-Kata, 4 (2).

Muslim. 2006. Nilai-Nilai Pendidikan Multikultural dalam Buku Teks Bahasa Indonesia untuk Siswa SMP. Jurnal Riksa Bahasa, 2 (1).

Nugrahani, Farida. 2014. Metode Penelitian Kualitatif: dalam Penelitian Pendidikan Bahasa. Surakarta: Cakra Books.

Prastowo, A. 2012. Panduan Kreatifmembuat Bahan Ajar Inovatif. Jogjakarta: Diva Press.

Raco. 2010. Langkah-langkah Metode Penelitian Kualitatif. Jakarta: PT. Gramedia Widisarana. 
Rampersad, I. 2014. Multiculturalism And The Challenge Of Managing Diversity In Trinidad And Tobago. Journal Of Social Science For Policy Implications, 2 (1).

Rindiasih, dkk. 2019. Buku Bahan Ajar Tematik Terpadu. Surakarta: CV Guci Pustaka.

Sabiyarti. 2018. Sehat itu Penting, Organ Gerak Manusia, Peristiwa dalam Kehidupan, Makanan Sehat, Ekosistem, Benda-benda di Sekitar Kita. Surakarta: CV Grahardi

Simamora, Artha Frida. 2015. Analisis Kebutuhan Kurikulum 2013 Pendidikan Multikultural Mata Pelajaran Bahasa Indonesia di Sekolah Menengah Atas Kota Surakarta. Surakarta: Universitas Sebelas Maret.

Sitepu. 2012. Penulisan Buku Teks Pelajaran. Bandung: Pt Remaja Rosdakarya.

Sugiyono. 2012. Metode Penelitian Pendidikan Pendekatan Kuantitatif, Kualitatif, Dan R \& D. Bandung: Penerbit Alfabeta.

Sutopo, H.B. 2002. Pengantar Penelitian Kualitatif. Surakarta: Universitas Sebelas Maret Press.

Tafsir. 2015. Pendidikan Multikultural Suatu Upaya Penguatan Jati Diri Bangsa. Bandung: Pustaka Setia.

Trisna, G. A. Putu Sukma. 2017. Pengembangan Pendidikan Multikultur Dalam Pembelajaran Bahasa Indonesia Di Sekolah Dasar. Jurnal Ilmiah Sekolah Dasar, 1 (2) 